\title{
12. HYDROCARBON MEASUREMENTS AT ARCTIC GATEWAYS SITES (ODP LEG 151) ${ }^{1}$
}

\author{
Ruediger Stein, ${ }^{2}$ Garrett Brass, ${ }^{3}$ Dennis Graham,${ }^{4}$ Anne Pimmel, ${ }^{4}$ and the Shipboard Scientific Party ${ }^{5}$
}

\begin{abstract}
As part of the Leg 151 shipboard safety and pollution monitoring program, concentrations of methane, ethane, and propane gases were routinely monitored in every core, using headspace and/or vacutainer techniques. In general, the vacutainer gas concentrations are higher than the headspace concentrations, but the trends of both records are similar. Except for Sites 907 and 913 , all sites are characterized by very high gas concentrations. Methane dominates the composition of the hydrocarbon gases at all sites; ethane and propane occur in minor, but significant amounts. In the lower part of the 1061.8-m-thick sedimentary sequence of Site 909 , higher molecular weight hydrocarbons $\left(C_{4}\right.$ to $\left.C_{7}\right)$ are also present. Despite high methane concentrations and pressure-temperature conditions in the stability field of gas hydrates, no obvious hydrates were recorded. A substantial increase in methane concentrations occurs immediately below the depth at which sulfate falls to zero, suggesting that methanogenesis is inhibited by the presence of sulfate and that intense sulfate reduction and methane oxidation occur at the interfaces. The $C_{1} / C_{2}$ ratios decrease with increasing depth or temperature due to the in-situ generation of $C_{2+}$ hydrocarbons during early (low-temperature) diagenesis of organic matter. At Site 909, a rapid and abrupt increase in heavier hydrocarbons was recorded near the bottom of the drill hole. Because of the low maturity of the organic matter, these hydrocarbons might have migrated from deeper sources.
\end{abstract}

\section{INTRODUCTION}

To study the paleoceanographic and tectonic history in the Arctic Gateway region, drilling was performed at seven sites on the Iceland Plateau (Site 907), in the Fram Strait (Sites 908 and 909), on the southern Yermak Plateau (Sites 910-912), and at the East Greenland continental margin (Site 913) during Ocean Drilling Program (ODP) Leg 151 (Fig. 1). At the different locations, 209.1- to 1061.8-m-thick sedimentary sequences of Quaternary to middle Eocene age were recovered (Thiede et al., this volume). The routine shipboard organic geochemistry program performed during this expedition concentrated on: (1) analyses of hydrocarbon gases, (2) determination of inorganic carbon concentrations, (3) elemental analyses of total nitrogen, carbon, and sulfur, and (4) pyrolysis of organic matter. The gas data primarily produced for safety and pollution-prevention considerations and the organic carbon data both allow a preliminary assessment of changes in paleoenvironment and diagenesis of the sediments. These preliminary conclusions will have to be substantiated by further detailed, shore-based organic geochemical investigations and interpreted in the context of stratigraphic, paleontological, and sedimentological data.

The major aims of this paper are (1) to summarize the results of the shipboard hydrocarbon monitoring program, (2) to compare headspace and vacutainer records, and (3) to interpret the shipboard

'Myhre, A.M., Thiede, J., Firth, J.V., et al., 1995. Proc. ODP, Init. Repts., 151: College Station, TX (Ocean Drilling Program).

${ }^{2}$ Alfred-Wegener-Institute for Polar and Marine Research, Columbusstrasse, D27568 Bremerhaven, Federal Republic of Germany.

${ }^{3}$ RSMAS-MGG, University of Miami, FL 33149, U.S.A.

${ }^{4}$ Ocean Drilling Program, Texas A\&M University Research Park, 1000 Discovery Drive, College Station, TX 77845, U.S.A.

5hipboard Scientific Party is as given in the list of participants preceding the Table of Contents. hydrocarbon data in terms of hydrocarbon origin, diagenesis, and safety considerations.

\section{METHODS}

\section{Vacutainer}

When gas voids or pockets occurred in the cores, gas samples were taken from the uncut liner using a liner penetrator with syringe attachment and evacuated glass container ("vacutainer"). A 5-ml gas volume was injected into the Carle (AGC series 100/Model 211) gas chromatograph immediately after sampling and analyzed for its composition (i.e., mainly $\mathrm{C}_{1}, \mathrm{C}_{2}$, and $\mathrm{C}_{3}$ hydrocarbons). Gas concentrations were calculated from comparison with gas standards. The results are presented in ppm concentrations of methane $\left(C_{1}\right)$, ethane $\left(\mathrm{C}_{2}\right)$, and propane $\left(\mathrm{C}_{3}\right)$.

\section{Headspace}

A headspace sample was taken at the bottom or top of a section from each core immediately after the core was on deck and cut into sections. A measured volume of sediment (about 5 to $7 \mathrm{~cm}^{3}$ ) was obtained by a cork borer with a calibrated plunger and placed into a 22 $\mathrm{cm}^{3}$ glass vial. When consolidated or lithified samples were encountered, chips of material were placed into the vial. The vial was sealed and heated to $70^{\circ} \mathrm{C}$ for $30 \mathrm{~min}$. A $5-\mathrm{mL}$ gas sample from the headspace inside the vial was then injected into the Carle gas chromatograph and analyzed for its $C_{1}, C_{2}$, and $C_{3}$ composition. Due to the occurrence of significant amounts of higher molecular-weight hydrocarbons $\left(\mathrm{C}_{2+}\right)$ in the lower part of the sedimentary sequence of Hole 909C, a second sample was injected into the Natural Gas Analyzer (modified Hewlett-Packard Model 5890a) (for details, see Emeis and Kvenvolden, 1986; Kvenvolden and McDonald, 1986). The results are expressed in ppm. In order to convert into concentration values of 


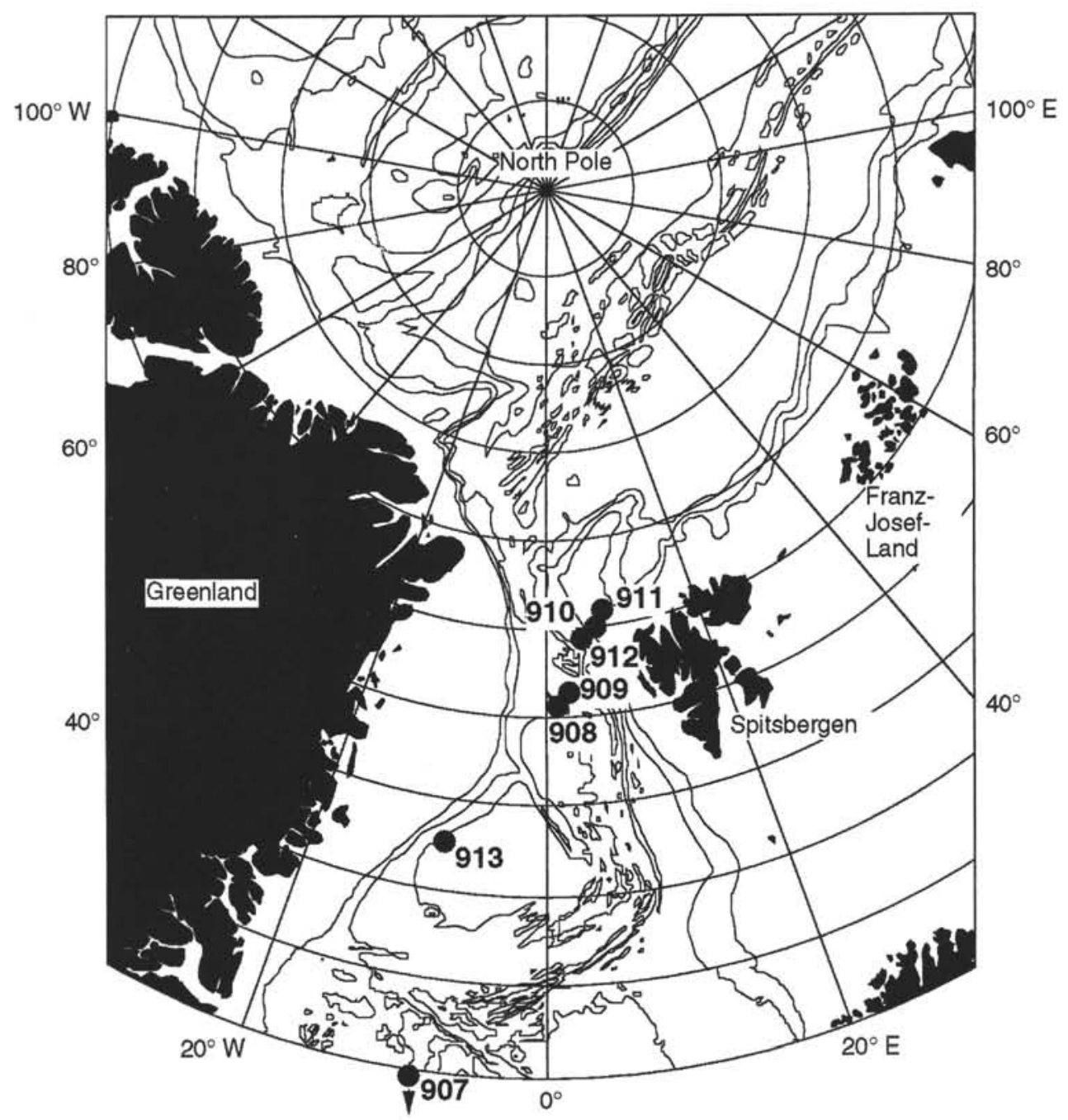

Figure 1. Map with the positions of Leg 151 sites.

$\mu \mathrm{L}$ gas $/ \mathrm{L}$ wet sediment, the ppm values have to be multiplied by the factor: (volume of headspace/volume of wet sediment). Using a mean sediment volume of about $6 \mathrm{~cm}^{3}$, this factor is 2.7 (cf. "Explanatory Notes" chapter of Suess, von Huene, et al., 1988).

\section{RESULTS AND DISCUSSION}

As part of the shipboard safety and pollution monitoring program, concentrations of methane $\left(C_{1}\right)$, ethane $\left(C_{2}\right)$, and propane $\left(C_{3}\right)$ gases were routinely monitored in every core (Figs. 2 and 3 ). In general, hydrocarbon concentrations were determined using the headspace technique. At Sites 909, 910, 911, and 912, gas voids were common, which also allowed hydrocarbon determinations on vacutainer gas samples. For these sites, a comparison of the hydrocarbon records obtained by the two different methods was possible (Fig. 3; see "Organic Geochemistry" section, "Site 912" chapter, this volume).

\section{Hydrocarbon Concentrations at Leg 151 Sites}

The predominant hydrocarbon determined at all Leg 151 sites is methane. Except for at Sites 907 and 913, sediments at all sites are characterized by very high methane concentrations (Fig. 2).

\section{Site 907}

Throughout the entire sediment sequence of Site 907, the headspace methane content remained low (4-5 ppm; Fig. 2). Ethane was not detected.

\section{Site 908}

Concentrations of headspace methane were low in the upper $90 \mathrm{~m}$ ( 3 to 10 ppm); ethane was not detected in this interval (Fig. 2). Below 90 mbsf, methane concentrations sharply increased by about three orders of magnitude reaching $10,000 \mathrm{ppm}$ at $150 \mathrm{mbsf}$. At that depth, ethane (2-3 ppm) was detected for the first time. Below $250 \mathrm{mbsf}$, traces of propane occurred ( 0.5 to $3 \mathrm{ppm})$.

\section{Site 909}

Except for the uppermost about $25 \mathrm{~m}$, concentrations of headspace methane were high throughout the sedimentary section, varying between about 10,000 and 75,000 ppm (Figs. 2 and 3). No distinct depth change is obvious. Minima in methane concentrations of $10,000-20,000$ ppm occurred in depth intervals of 70-80 mbsf, 220 270 mbsf, $370-390 \mathrm{mbsf}, 430-450 \mathrm{mbsf}$, and $710-750 \mathrm{mbsf}$. Most of these minima are paralleled by minima in ethane and propane as well. The minima are even more pronounced in the vacutainer records 


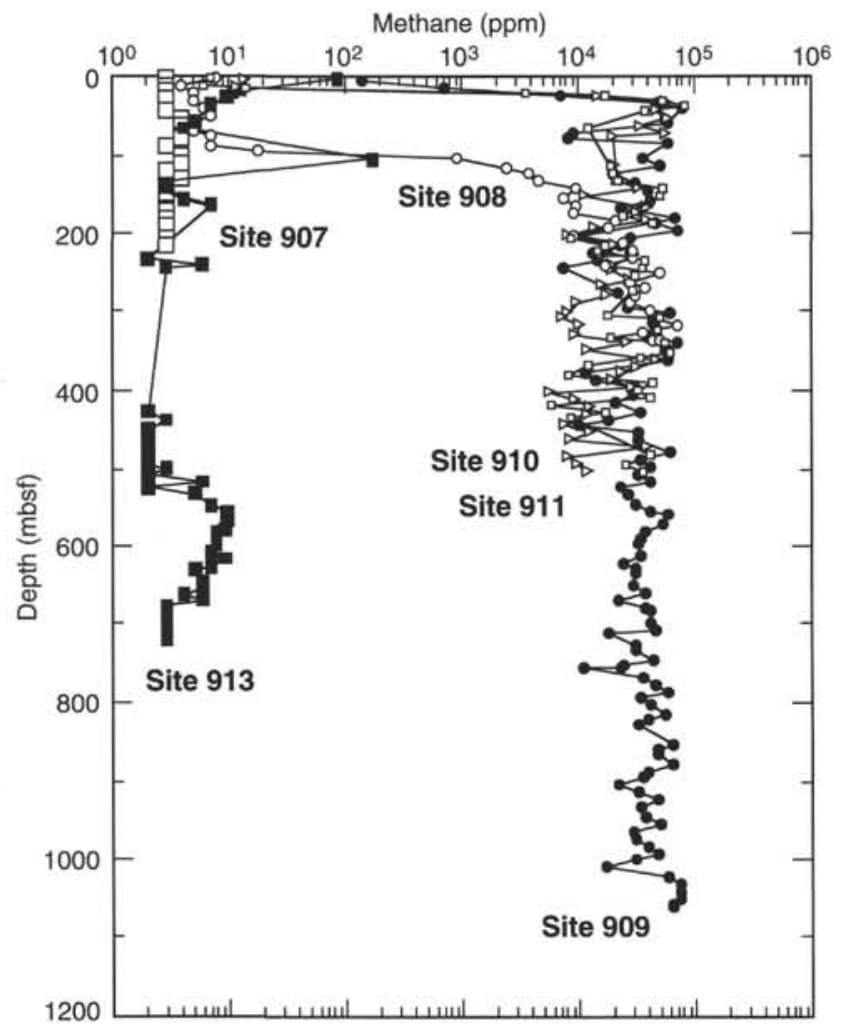

Figure 2. Headspace methane concentrations vs. depth at Sites 907, 908, 909 , 910,911 , and 913.

(Fig. 3). In general, ethane consistently increases downhole, from values $<10 \mathrm{ppm}$ typical for the upper $100 \mathrm{~m}$ to about $1500 \mathrm{ppm}$ at the bottom of the hole. Propane concentrations are low in the upper 400 mbsf $(<10 \mathrm{ppm})$, increasing to values of almost $200 \mathrm{ppm}$ between 400 and 1010 mbsf. Between 1010 and 1060 mbsf, a sharp two-step increase in propane was recorded (i.e., to almost $500 \mathrm{ppm}$ at 1010 mbsf and to $>900 \mathrm{ppm}$ at $1045 \mathrm{mbsf}$; Fig. 3). Below $440 \mathrm{mbsf}$, higher-molecular-weight hydrocarbons $\left(\mathrm{C}_{4}\right.$ to $\left.\mathrm{C}_{7}\right)$ occurred in detectable amounts (see below).

\section{Site 910}

Except for the uppermost about $20 \mathrm{~m}$, concentrations of headspace methane were high throughout the sedimentary section, ranging from about 10,000 to 80,000 ppm (Fig. 3). Minimum methane concentrations of less than $10,000 \mathrm{ppm}$, however, were recorded at about $200 \mathrm{mbsf}, 380 \mathrm{mbsf}$, and between 420 and $440 \mathrm{mbsf}$. Ethane and propane values occurred in detectable amounts below $20 \mathrm{mbsf}$ as well and show a distinct downhole increase. At about $500 \mathrm{mbsf}$, ethane and propane concentrations reach maximum concentrations of 80 to almost 100 ppm (Fig. 3). In the vacutainer records distinct minima in methane, ethane, and propane concentrations are obvious at depths of 200-250 mbsf and 400-450 mbsf.

\section{Site 911}

The headspace methane record at Site 911 is very similar to that at Site 910 ; high values of 10,000 to $60,000 \mathrm{ppm}$ are dominant, and no long-term change is obvious (Fig. 3). First minor amounts of ethane and propane were determined below about $50 \mathrm{mbsf}$. Below this depth, ethane and propane consistently increase downhole, reaching maximum concentrations of $40 \mathrm{ppm}$ and $15 \mathrm{ppm}$, respectively, at the bottom of the hole (Fig. 3). The vacutainer concentrations show general trends similar to the headspace values, but they are systematically higher. Furthermore, distinct minima in gas concentrations are obvious at 80-110 mbsf, 210-230 mbsf, 280-330 mbsf, and 400-440 mbsf (Fig. 3).

\section{Site 912}

The headspace methane record at Site 912 displays a trend similar to those described for Sites 910 and 911: The upper about $11.5 \mathrm{~m}$ of the sedimentary sequence of Site 912 are characterized by very low headspace methane concentrations of 7-18 ppm. Between 11.5 and 23 mbsf, methane concentration distinctly increased from 18 to almost its maximum value of $40,000 \mathrm{ppm}$. First minor amounts of headspace ethane $(2-8 \mathrm{ppm})$ and propane $(1-3 \mathrm{ppm})$ were determined below about $20 \mathrm{mbsf}$. The vacutainer concentrations of methane reach about $60,000 \mathrm{ppm}$; ethane and propane vary between 67 and $138 \mathrm{ppm}$ and between 3 and $5 \mathrm{ppm}$, respectively, increasing downhole (see "Organic Geochemistry" section, "Site 912" chapter, this volume).

\section{Site 913}

Throughout the 770.3-m-thick sedimentary section of Site 913 , headspace methane concentrations are very low. Almost all of the values are $<10 \mathrm{ppm}$, i.e. about four orders of magnitude lower than those recorded at Sites 909-911 (Fig. 2). Only in the uppermost sample at about $3 \mathrm{mbsf}$ and near $105 \mathrm{mbsf}$, some slightly elevated methane values of $84 \mathrm{ppm}$ and $172 \mathrm{ppm}$, respectively, occurred. In the interval between 550 and 660 mbsf where methane reached concentrations of up to $10 \mathrm{ppm}$ (Fig. 2), traces of ethane were determined, too.

\section{Headspace vs. Vacutainer Data}

In general, the vacutainer gas concentrations are higher than the headspace concentrations (Fig. 3). They show, however, similar trends. The differences between headspace and vacutainer data can be explained by the different sampling techniques. The headspace methane concentrations are probably minimum values because these amounts are the upper limit of methane that can be retained by the sediment as it is brought on deck and decompresses to atmospheric pressure (Suess, von Huene, et al., 1988). This means there is a significant loss of hydrocarbons before the headspace sediment sample is sealed in the glass vial. This appears to be important especially for the more mobile methane, resulting in a relative enrichment of ethane in the headspace sample and, thus, lower $\mathrm{C}_{1} / \mathrm{C}_{2}$ ratios (see below). It is also possible that the heating time of $30 \mathrm{~min}$ is too short, and/or the headspace volume is too small to mobilize all hydrocarbons from the pore water of the sediment into the headspace.

A further difference between the headspace and vacutainer records is the distinct minima in hydrocarbon concentrations obvious in the vacutainer data of Sites 909, 910, and 911. These minima are absent or much less pronounced in the headspace data (Fig. 3). These distinct variations in gas concentrations may suggest distinct variations in primary gas production and/or lithologic parameters such as porosity, grain size, etc. On first view it appears that some of the minima coincide with organic carbon minima, suggesting a decrease in primary gas production. On the other hand, at numerous other ODP and DSDP sites these distinctly reduced gas concentrations were described and explained by air contaminations (e.g., Suess, von Huene, et al., 1988). This explanation cannot be excluded for the Leg 151 Sites. A more detailed comparison of the gas data with other lithologic as well as geochemical parameters should help to distinguish among possible reasons for the variations in gas content. 
Site 909
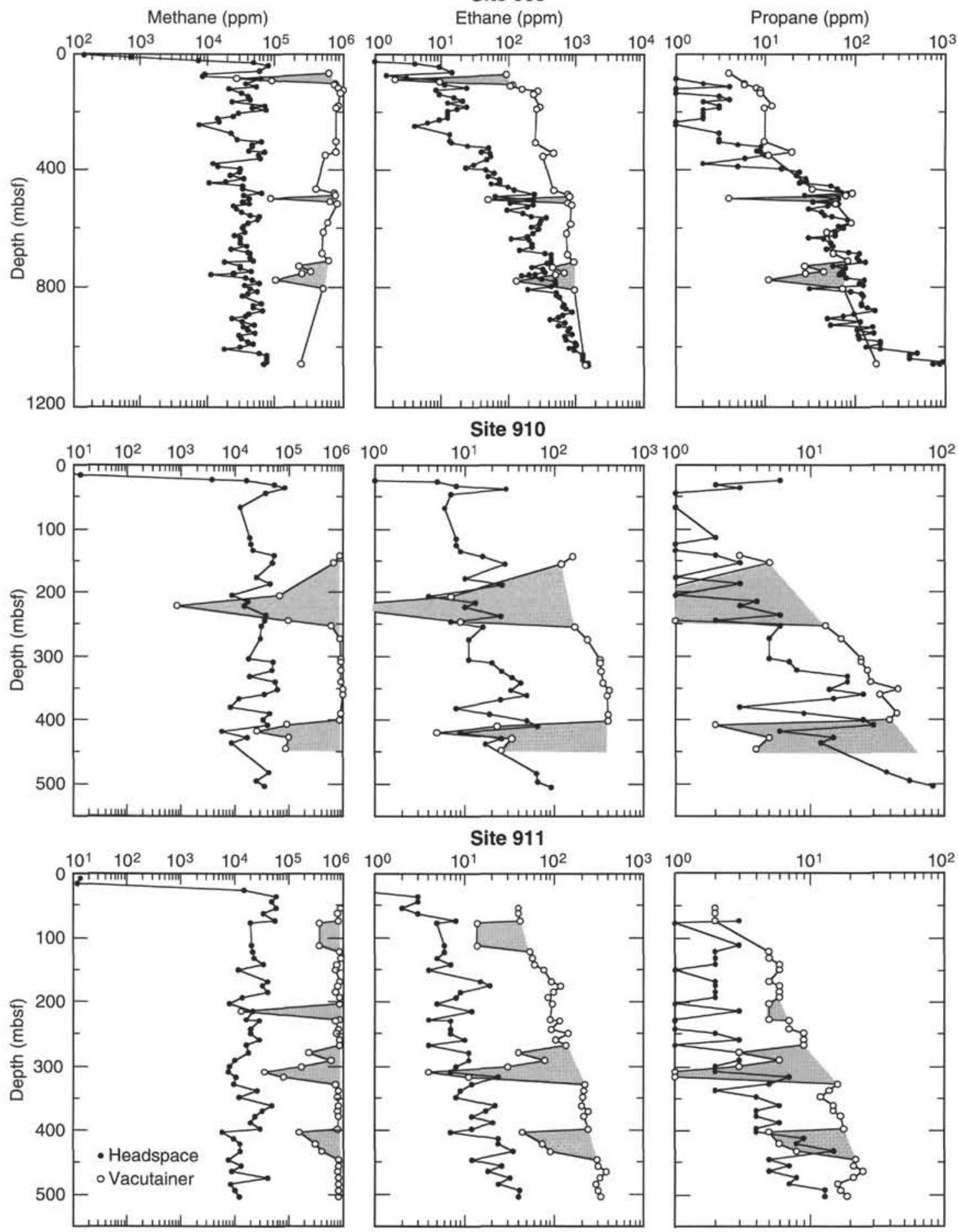

Figure 3. Headspace (solid circles) and vacutainer (open circles) concentrations of methane, ethane, and propane at Sites 909, 910, and 911. The shaded areas emphasize distinct minima in vacutainer gas concentrations.

\section{$\mathrm{C}_{1} / \mathrm{C}_{2}$ Records: Hydrocarbon Origin and Safety Considerations}

The most common method of hydrocarbon monitoring used in DSDP and ODP operations for safety considerations has been vacutainer gas analysis and the presentation of the results in terms of $\mathrm{C}_{1} /$ $\mathrm{C}_{2}$ ratios vs. depth (cf. Fig. 4; JOIDES PPSP, 1992). These $\mathrm{C}_{1} / \mathrm{C}_{2}$ ra- tios provide initial information about the origin of the hydrocarbons, in that they distinguish between biogenic gas and gas migrated from a deeper source of thermogenic hydrocarbons. Very high $C_{1} / C_{2}$ ratios indicate methane formation by microbiological processes. On the other hand, major amounts of $\mathrm{C}_{2}$ (to $\mathrm{C}_{5}$ ) hydrocarbons, and thus low $\mathrm{C}_{1} / \mathrm{C}_{2}$ ratios, are associated with thermogenic hydrocarbon generation. During earlier phases of DSDP, a termination of drilling was re- 

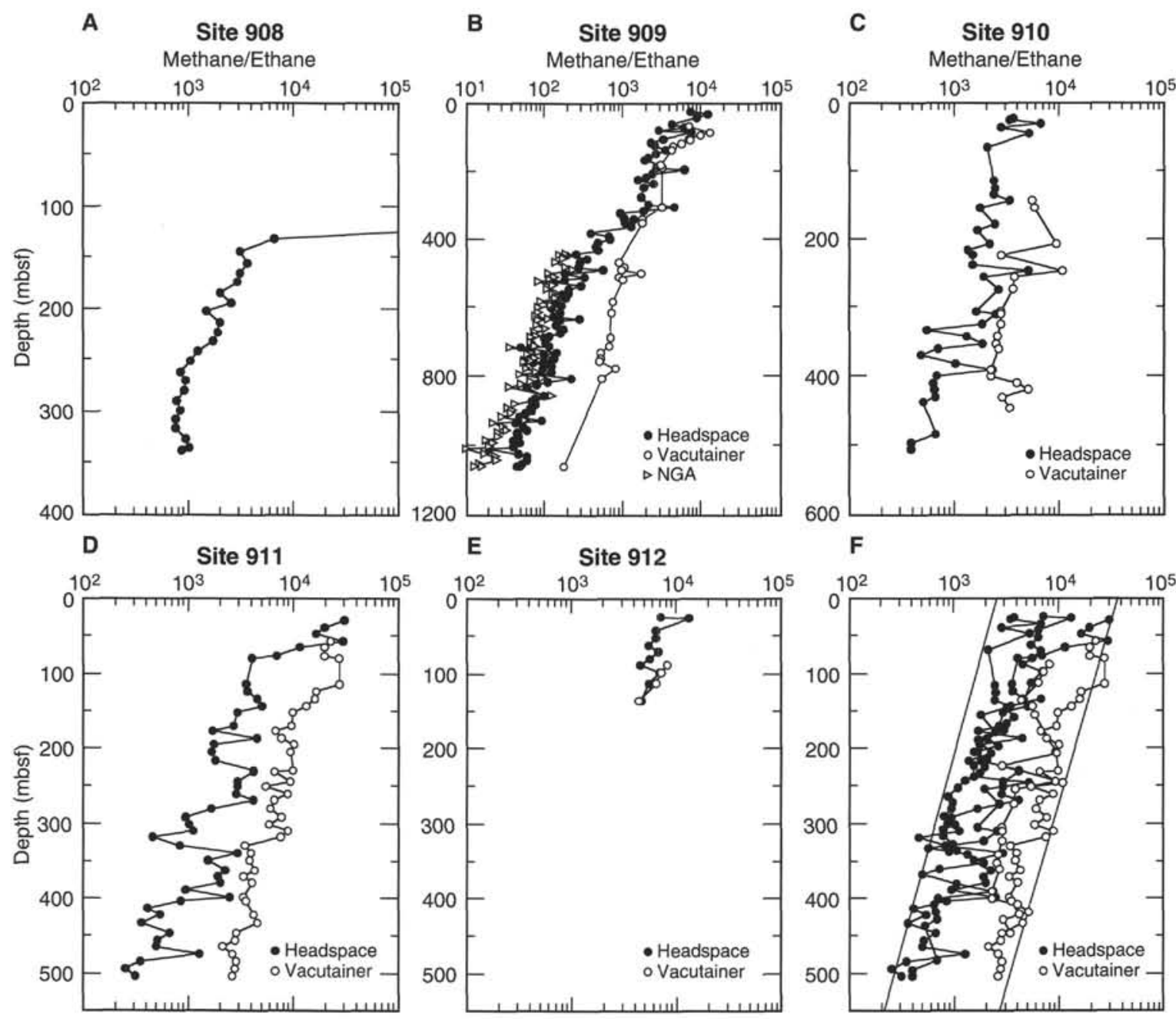

Figure 4. Methane/ethane $\left(C_{1} / C_{2}\right)$ ratios at Leg 151 sites plotted vs. depth. For Site 909, Natural Gas Analyzer (NGA) data are also shown (open triangles). In Figure $4 \mathrm{~F}, \mathrm{C}_{1} / \mathrm{C}_{2}$ ratios for all sites are plotted in a summary diagram.

quired whenever the $C_{1} / C_{2}$ ratios decreased to values of less than 1000 .

An updated compilation of gas records using all DSDP and more recent ODP data from a variety of geologic settings, however, indicates that $\mathrm{C}_{1} / \mathrm{C}_{2}$ ratios of $<1000$ do not indicate a critical situation (JOIDES PPSP, 1992). When interpreting the $C_{1} / C_{2}$ ratios, we need to consider that minor amounts of $\mathrm{C}_{2}$ (and $\mathrm{C}_{3}, \mathrm{C}_{4}, \mathrm{C}_{5}$ ) compounds can also be generated in situ during early (low-temperature) diagenesis of organic matter (e.g., Kvenvolden and Barnard, 1983). The importance of this process increases with increasing burial, resulting in a consistent ("normal") decrease in $\mathrm{C}_{1} / \mathrm{C}_{2}$ with increasing depth or temperature (Fig. 5; JOIDES PPSP, 1992). Based on this relationship, "anomalously" low $C_{1} / C_{2}$ ratios at shallow depth or at low temperatures suggest the presence of migrated thermogenic hydrocarbons (Fig. 5). It should be mentioned that the "normal" field is based on DSDP/ODP vacutainer data (original plot of JOIDES PPSP, 1992). According to our results, the "normal" field may be extended to lower $\mathrm{C}_{1} / \mathrm{C}_{2}$ ratios in the low-temperature part of the record when using headspace data (light-dotted field in Fig. 5).

The $C_{1} / C_{2}$ ratios at Sites $908-912$ are generally high, suggesting a biogenic origin of the methane (Fig. 4). It was probably formed by insitu microbial fermentation of the marine organic carbon, which is present in major amounts in the lower part of the sedimentary sequence (see "Organic Geochemistry" sections of this volume). Simi- lar in-situ microbial methane production from marine organic carbon resulting in high biogenic gas concentrations has been described at other DSDP/ODP sites (e.g., at the Walvis Ridge; Meyers and Brassell, 1985). Furthermore, the records show the normal consistent decrease in $\mathrm{C}_{1} / \mathrm{C}_{2}$ ratios with increasing depth or temperature (Figs. 4 and 5).

The vacutainer data also show a downhole decrease in $\mathrm{C}_{1} / \mathrm{C}_{2}$ ratios, but with an offset toward higher values (see above). On the other hand, the $\mathrm{C}_{1} / \mathrm{C}_{2}$ ratios derived from NGA (Natural Gas Analyzer) measurements of headspace samples from Site 909 are slightly lower, but show exactly the same trend as the headspace $C_{1} / C_{2}$ ratios derived from the Hach-Carle analyses (Fig. 4). In the lower, higher-temperature part of the sedimentary record, $C_{1} / C_{2}$ ratios probably do not indicate "dangerous" situations and the presence of migrated hydrocarbons, as shown for the 909 data (see below).

\section{Methane Formation and Diagenesis}

In general, sediments showing high methane concentrations are also characterized by relatively high organic carbon contents and high sedimentation rates. Under these conditions, the decomposition of the organic matter is dominated by anaerobic microbial processes (i.e., sulfate reduction and carbonate reduction/methane production; Claypool and Kaplan, 1974; Claypool and Kvenvolden, 1983; Suess, 


\section{A Methane/Ethane $\left(C_{1} / C_{2}\right)$}

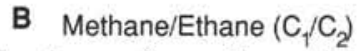

C Methane/Ethane $\left(C_{1} / C_{2}\right)$

D Methane/Ethane $\left(C_{1} / C_{2}\right)$
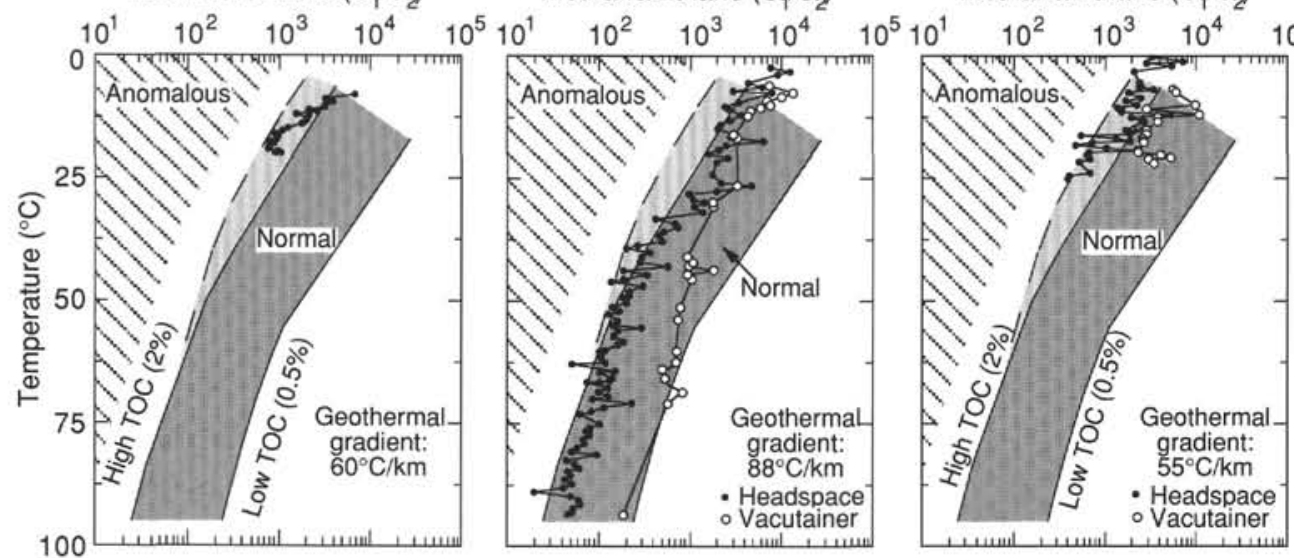

$\begin{array}{lllll}10^{5} 10^{1} & 10^{2} & 10^{3} & 10^{4} & 10^{5}\end{array}$

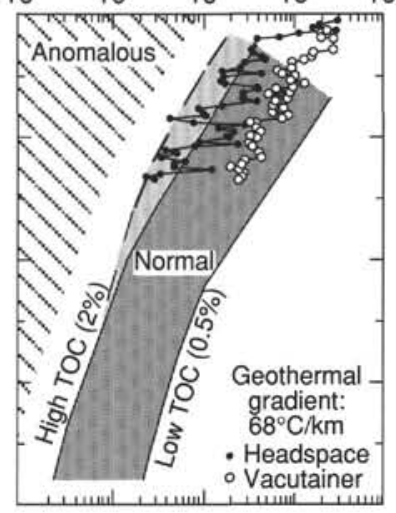

Figure 5. Relationship between (biogenic) gas composition expressed as $C_{1} / C_{2}$ ratio and sediment temperature at depth, based on DSDP/ODP drilling results (after JOIDES PPSP, 1992). The dotted field marks the "normal" range of $C_{1} / C_{2}$ ratios; the hatched field marks "anomalous" $C_{1} / C_{2}$ ratios suggesting migrated thermogenic hydrocarbons. The influence of different quantities of organic carbon is shown by the two lines. According to our results, the "normal" field may be extended to lower $\mathrm{C}_{1} / \mathrm{C}_{2}$ ratios in the low-temperature part of the record when using headspace data (light-dotted field). Uncorrected geothermal gradients used. For determination of geothermal gradient and corrected gradients, see the site chapters of this volume. The corrected geothermal gradients will not change the general trend significantly. A. Hole 908A; B. Site 909; C. Hole 910C; D. Hole 911A.
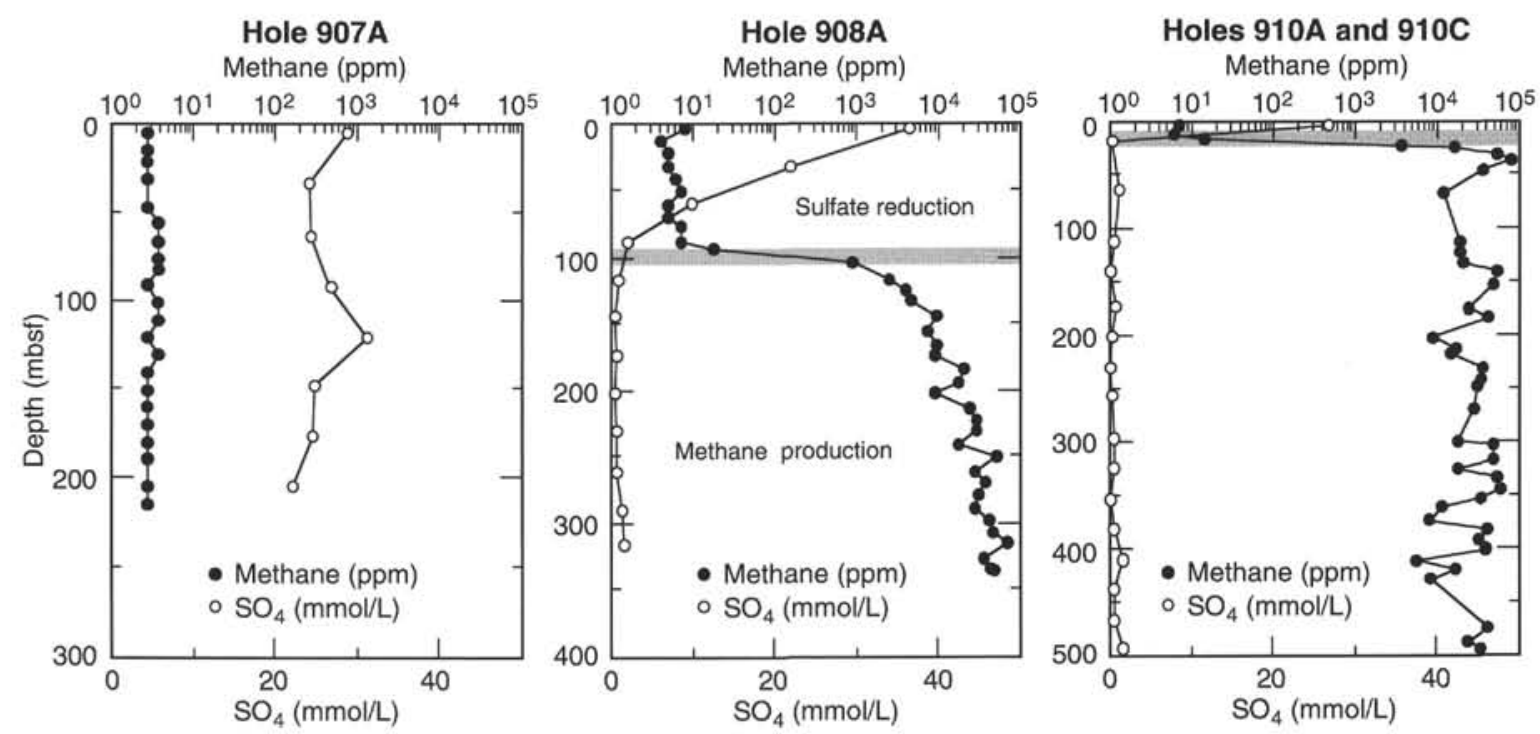

Figure 6. Profiles of methane and sulfate concentrations as a function of depth at Sites 907, 908, and 910. Stippled bar indicates the boundary between sulfate reduction and methane production. The methane and sulfate profiles at Sites 909,911, and 912 are similar to those from Site 910.

von Huene, et al., 1988). At Site 908 , methane production has begun at depths between 90 and 105 mbsf; and at Sites 909 through 911 , methane production has already begun at depths shallower than 25 mbsf (Fig. 2). At all sites, the rapid increase in methane concentration commences with the disappearance of sulfate (Fig. 6). This inverse correlation strongly suggests that methane results from methanogenesis, which is inhibited in the presence of sulfate. These results support the microbial sulfate reduction-methane production model of Claypool and Kaplan (1974). The depth of the boundary between the sulfate reduction and methane production zones is mainly controlled by the dynamics between bulk sedimentation rate and diffusional supply of sulfate (Claypool and Kaplan, 1974; Suess, von Huene, et al., 1988; Kvenvolden et al., 1990). This explains the deeper onset of methanogenesis at Site 908 where the mean sedimentation rate is lower than that determined for Sites 909-912 (Fig. 7).
The very steep gradients in sulfate and methane near their minima indicate a substantial flux of methane and sulfate toward this interface from below and above, respectively. The sulfate and methane diffusing toward this interface must be consumed by sulfate reduction and methane oxidation. It is, however, clear from the ammonia distributions in cores from Leg 151 (see "Inorganic Geochemistry" sections of this volume) that oxygen is not present at the interface and is, in most cores, probably restricted to very near the sediment-water interface. The nature of the oxidant for methane consumption at the interface is, as a consequence, not oxygen. The distributions of sulfate, methane, and ammonia in these cores clearly indicate the reduction of sulfate by methane oxidation.

At Sites 907 and 913, methane generation was inhibited by the presence of sulfate ions down to the bottom of the holes (Fig. 6; see "Inorganic Geochemistry" sections, "Site 907" and "Site 913" chap- 


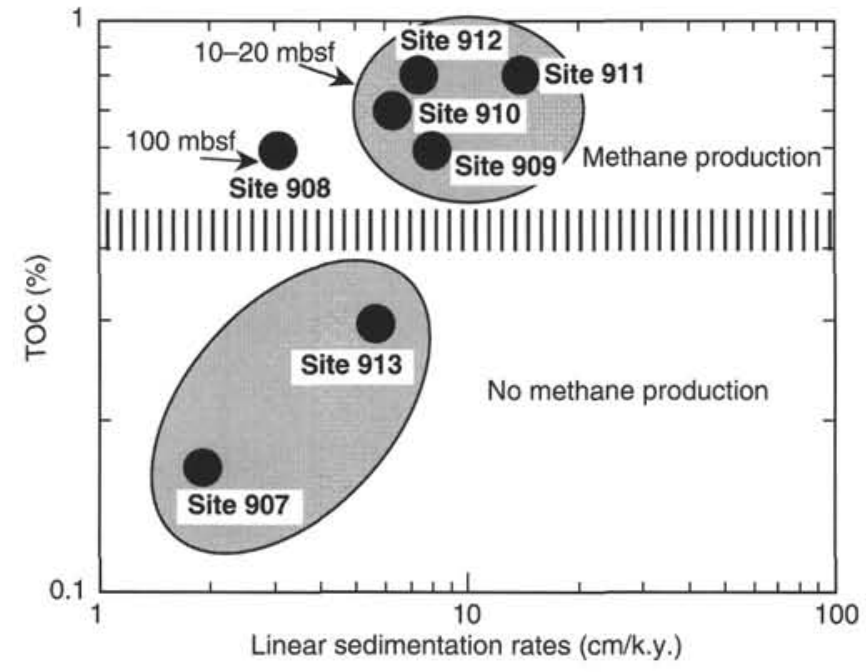

Figure 7. Total organic carbon content vs. linear sedimentation rate plot for the Quaternary sedimentary sequences of Sites $907-913$. Horizontal hatched bar indicates boundary between methane production and no-methane production. At Site 908, methane production started at about $100 \mathrm{mbsf}$; at Sites 909-912, methane production started between 10 and $20 \mathrm{mbsf}$ (see text for further explanation).

ters, this volume). Low organic carbon contents and low sedimentation rates (Fig. 7) recorded at Sites 907 and 913 may be responsible for these differences. According to Claypool and Kaplan (1974), methane production requires a minimum organic carbon content of about $0.5 \%$ to allow anoxic conditions to be established in the sediment column. Certainly, the composition of the organic matter fraction (i.e., its marine and terrigenous proportions) will influence methanogenesis, too.

\section{Methane Formation and Gas Hydrates}

Although no obvious gas hydrates were encountered at the Leg 151 sites, the very high methane concentrations of 50,000 to 90,000 ppm (or about $1.5-3 \times 10^{5} \mu \mathrm{L} / \mathrm{L}$ ) determined in several shallow intervals may possibly be related to the presence of hydrates. At such high methane concentrations, which exceed the saturation level in water, gas hydrates may be formed (Kvenvolden and McMenamin, 1980). According to the pressure-temperature stability field of gas hydrates (Claypool and Kaplan, 1974; Hedberg, 1980; Kvenvolden and Barnard, 1983), with geothermal temperature gradients between $60^{\circ}$ and $90^{\circ} \mathrm{C}$ (see site chapters in this volume), water depths between about 600 and $3400 \mathrm{~m}$, and bottom water temperatures of about $0^{\circ} \mathrm{C}$, gas hydrates are stable down to about 100 to $300 \mathrm{mbsf}$ at the different Leg 151 sites.

At Site 910, for example, gas hydrates should be stable down to about $210 \mathrm{mbsf}$. The maximum concentration of headspace methane of $60,000-90,000 \mathrm{ppm}$ (or about $1.6-2.7 \times 105 \mu \mathrm{L} / \mathrm{L}$ ) at $40 \mathrm{mbsf}$ and around $150 \mathrm{mbsf}$ may be related to the presence of hydrates. The very high gas concentrations at about 150 mbsf indicated by the first occurrence of major gas voids, degassing sediments (pronounced "bubbling") in the core liner, and strong bulging of end caps, may support this. No obvious gas hydrates, however, were observed in Hole 910C. The pore-water geochemistry also does not give a clear signal for the occurrence of hydrates (see "Inorganic Geochemistry" sections of this volume). We might expect anomalies in pore-water sodium and chloride contents if a significant amount of hydrate had formed in the pore spaces of the sediment and then melted during coring. Such an effect might not appear if the process of hydrate formation cemented the interstitial volume and, as a consequence, inhibited the advection of brines formed by salt rejection during clathrate formation and the diffusion of salts out of the brines. Subsequent melting of the gas hydrate would return water to the system, restoring salt concentrations to their original values. This explanation, although somewhat ad hoc, allows us to reconcile the lack of hydrate formation effects in the inorganic geochemistry with the prediction of hydrate formation from thermodynamic data.

\section{Hydrocarbon Formation/Migration at Site 909}

At Site 909, where sediments were penetrated to a depth of 1061.8 mbsf, also higher molecular weight hydrocarbons were determined in the lower half of the sedimentary sequence (Fig. 8). Isobutane, $n$-butane, isopentane, and $n$-pentane started to occur at $440 \mathrm{mbsf}$; isohexane started to occur at $700 \mathrm{mbsf}$; and $n$-hexane and $n$-heptane started to occur below 970 mbsf. The presence of these heavier hydrocarbons and the consistent increase of their relative concentrations with increasing depth (or temperature) may indicate the beginning of significant thermogenic hydrocarbon formation. Under these temperature conditions of $>60^{\circ} \mathrm{C}$ (cf. Fig. 5), the occurrence of $\mathrm{C}_{5}-\mathrm{C}_{7}$ hydrocarbons and their smooth increase with depth are "normal" and have been reported before for other DSDP and ODP sites (e.g., Sites 467 and 471; Whelan and Hunt, 1981; Site 603, Schaefer and Leythaeuser, 1987).

Below 1010 mbsf, however, a major change in the hydrocarbon composition was recorded. A drastic and abrupt increase in heavier hydrocarbons $\left(\mathrm{C}_{3}-\mathrm{C}_{7}\right)$ occurred in two steps at $1010 \mathrm{mbsf}$ and 1050 mbsf. As shown in Figure 8, propane, isobutane, $n$-butane, isopentane, and $n$-pentane increased by a factor of 5 to 10 . Significant amounts of cyclopentanes and cyclohexanes were also determined (Fig. 9). Furthermore, a strong light-yellow fluorescence of the sediment and a white-blue fluorescence of the fluid occurred after treatment with 1,1,1-trichloroethane as solvent in samples from Cores 151-909C-102 and -103 ("cut fluorescence"), indicating the presence of liquid hydrocarbons. In the same cores, the drilling time was distinctly increased because the sediment became significantly harder. Thus, the possibility that a cap rock had been reached could not be excluded, and drilling had to be terminated immediately for safety and pollution prevention considerations.

The sharp increase in gas concentrations in the lowermost part of the drill hole appears to be parallel to an increase in total organic carbon contents (1.5\% to $2 \%$; Fig. 10). Furthermore, shore-based RockEval data (for method see Espitalié et al., 1977) indicate a major change in the composition and thermal maturity of the organic matter fraction (Fig. 10). The S2 values, a measure for the quantity of hydrocarbons that could be produced in these sediments by cracking the kerogen, are distinctly higher in these lower cores. Increased hydrogen index (HI) values and low temperatures of maximum pyrolysis yield ( $T_{\max }$ values) suggest the presence of immature mixed (marine + terrigenous) organic material. This is also supported by the position of the data points in the hydrogen index/oxygen index ("van Krevelen-type") diagram (Fig. 11, encircled field) as well as the relationship between $\mathrm{T}_{\max }$ values and the Production Index [S1/(S1+S2)] (Fig. 12).

According to the total organic carbon contents $(1 \%-2.5 \%), \mathrm{S} 1$ and S2 values of $0.4-0.9 \mathrm{mg} \mathrm{HC} / \mathrm{g}$ rock and $2-6 \mathrm{mg} \mathrm{HC} / \mathrm{g}$ rock, respectively, hydrogen index values of 150 to $250 \mathrm{mg} \mathrm{HC} / \mathrm{gC}$, and $\mathrm{T}_{\max }$ values of $425^{\circ}$ to $435^{\circ} \mathrm{C}$, the sedimentary rocks recovered near the bottom of Hole 909C appear to be a source rock with a reasonably good potential for gas and oil, but at a fairly low level of thermal maturity (Table 1; cf. Peters, 1986). Because of the low maturity, the light hydrocarbons determined in the lowermost part of the sedimentary sequence are likely to have migrated from other (deeper) areas.

In the depth interval between about 760 and $970 \mathrm{mbsf}$, on the other hand, high $\mathrm{T}_{\max }$ values of $>450^{\circ} \mathrm{C}$ (Fig. 10) as well as low hydrogen 


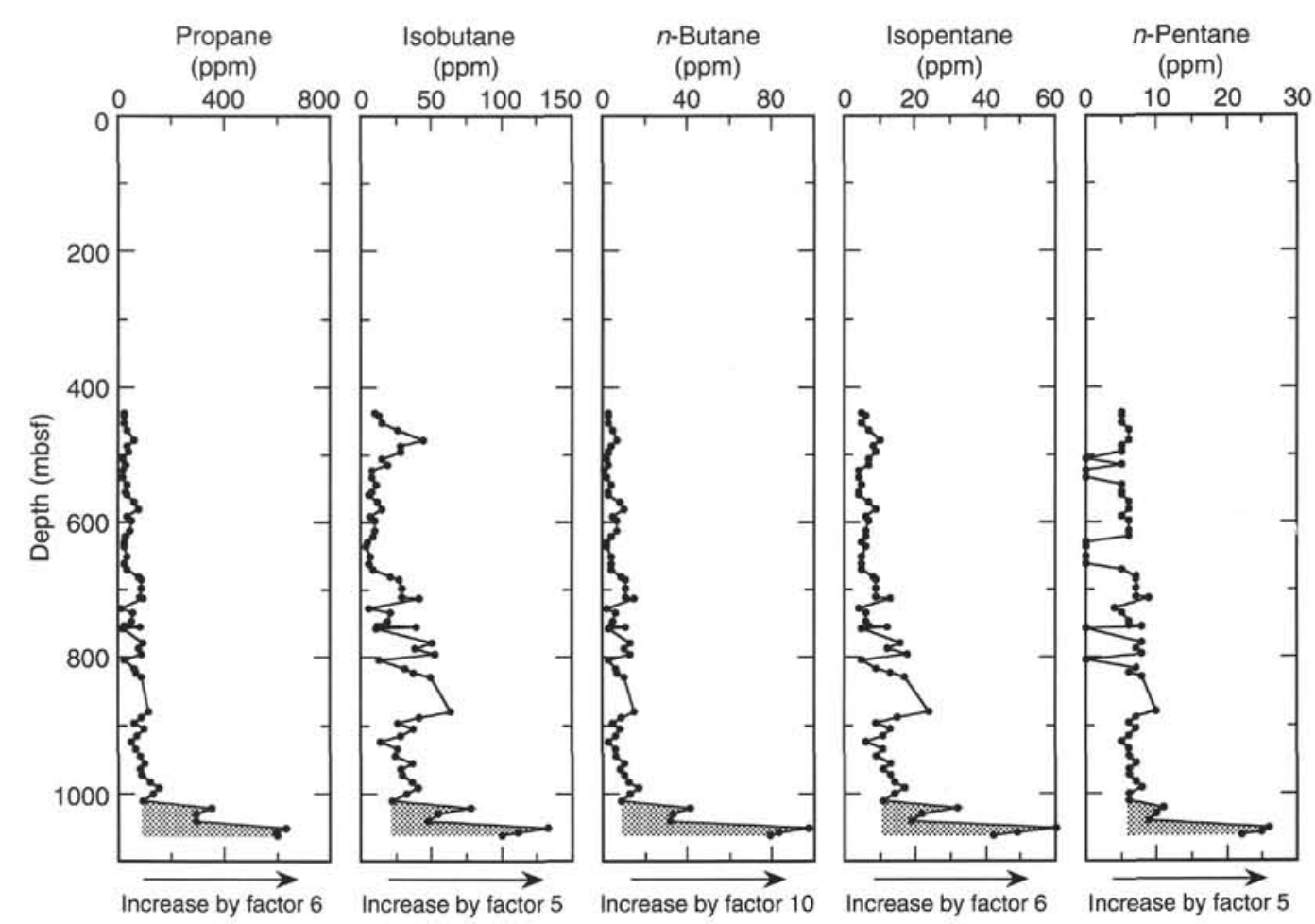

Figure 8. Profiles of natural gas analyzer concentrations of propane, isobutane, $n$-butane, isopentane, and $n$-pentane at Site 909 , plotted vs, depth. In the lowermost part of the records, a distinct increase in gas concentrations by a factor of 5 to 10 is obvious.

and oxygen index values (i.e., a position close to the origin in the HI/ OI diagram; Fig. 11) indicate the presence of mature organic matter. This is indicative of an increased supply of reworked, inert (terrigenous?) material (cf. Fig. 12).

\section{CONCLUSIONS}

The results of the routine shipboard organic geochemistry program can be summarized as follows:

1. High methane concentrations were recorded at all Leg 151 sites, except Sites 907 and 913. Ethane and propane occurred in minor but significant amounts. Despite high methane concentrations and pressure-temperature conditions favorable for gas-hydrate formation, no real hydrates were found.

2. Whenever sulfate concentrations approach zero, methane concentrations rapidly increase, suggesting methane production from methanogenesis.

3. $C_{1} / C_{2}$ ratios consistently decrease with increasing depth and temperature, caused by the increasing importance of in-situ generation of $\mathrm{C}_{2+}$ hydrocarbons during early (low-temperature) diagenesis of organic matter.

4. At Site 909, distinctly increased amounts of higher-molecularweight hydrocarbons $\left(\mathrm{C}_{3}-\mathrm{C}_{7}\right)$ were recorded in the deeper part of the drill hole. The low-maturity level of the organic matter suggests migration of hydrocarbons from deeper sources.

More detailed conclusions regarding thermal maturity and quality of the organic matter as well as further conclusions about migration and/or in-situ formation of hydrocarbons need support by other more precise geochemical methods, such as gas chromatography, gas chromatography/mass spectrometry, and kerogen microscopy studies.

\section{ACKNOWLEDGMENTS}

We gratefully thank Gene Pollard, ODP Drilling Superintendent, and the drilling crew, as well as the captain and the crew of JOIDES Resolution for cooperation during Leg 151. We thank J. Rullkötter (ICBM, Oldenburg University) and W. Michaelis (Hamburg University) for reviewing the manuscript. This is contribution No. 749 of the Alfred-Wegener-Institute for Polar and Marine Research, Bremerhaven, Federal Republic of Germany.

\section{REFERENCES*}

Claypool, G.E., and Kaplan, I.R., 1974. The origin and distribution of methane in marine sediments. In Kaplan, I.R. (Ed.), Natural Gases in Marine Sediments: New York (Plenum), 99-139.

Claypool, G.E., and Kvenvolden, K.A., 1983. Methane and other hydrocarbon gases in marine sediment. Annu. Rev. Earth Planet. Sci., 11:299-327.

Emeis, K.-C., and Kvenvolden, K.A., 1986. Shipboard organic geochemistry on JOIDES Resolution. ODP Tech. Note, 7.

Éspitalié, J., Laporte, J.L., Leplat, P., Madec, M., Marquis, F., Paulet, J., and Boutefeu, A., 1977. Méthode rapide de caractérisation des roches mères, de leur potentiel pétrolier et de leur degré d'évolution. Rev. Inst. Fr. Pet., 32:23-42.

Hedberg, H.D., 1980. Methane generation and petroleum migration. In Roberts, W.H., III, and Cordell, R.J. (Eds.), Problems of Petroleum Migration. AAPG Stud. in Geol., 10:179-206.

JOIDES PPSP, 1992. Ocean Drilling Program guidelines for pollution prevention and safety. JOIDES J., 18.

*Abbreviations for names of organizations and publications in ODP reference lists follow the style given in Chemical Abstracts Service Source Index (published by American Chemical Society). 
Kvenvolden, K.A., and Barnard, L.A., 1983. Gas hydrates of the Blake Outer Ridge, Site 533, Deep Sea Drilling Project Leg 76. In Sheridan, R.E., Gradstein, F.M., et al., Init. Repts. DSDP, 76: Washington (U.S. Govt. Printing Office), 353-365.

Kvenvolden, K.A., Frank, T.J., and Golan-Bac, M., 1990. Hydrocarbon gases in Tertiary and Quaternary sediments offshore Peru-results and comparisons. In Suess, E., von Huene, R., et al., Proc. ODP, Sci. Results, 112: College Station, TX (Ocean Drilling Program), 505-515.

Kvenvolden, K.A., and McDonald, T.J., 1986. Organic geochemistry on the JOIDES Resolution-an assay. ODP Tech. Note, 6.

Kvenvolden, K.A., and McMenamin, M.A., 1980. Hydrates of natural gas: a review of their geologic occurrence. Geol. Surv. Circ. (U.S.), 825.

Meyers, P.A., and Brassell, S.C., 1985. Biogenic gases in sediments deposited since Miocene times on the Walvis Ridge, South Atlantic Ocean. In Caldwell, D.E., Brierly, J.A., and Caldwell, C.L. (Eds.), Planetary Ecology: New York (Van Nostrand Reinhold), 69-80.

Peters, K.E., 1986. Guidelines for evaluating petroleum source rock using programmed pyrolysis. AAPG Bull., 70:318-329.

Schaefer, R.G., and Leythaeuser, D., 1987. Low-molecular-weight hydrocarbons in sediments of Deep Sea Drilling Project Leg 93, Hole 603B, off the east coast of North America. In van Hinte, J.E., Wise, S.W., Jr., et al., Init. Repts. DSDP, 93 (Pt. 2): Washington (U.S. Govt. Printing Office), $1237-1244$.

Suess, E., von Huene, R., et al., 1988. Proc. ODP, Init. Repts., 112: College Station, TX (Ocean Drilling Program).

Whelan, J.K., and Hunt, J.M., 1981. $\mathrm{C}_{1}-\mathrm{C}_{8}$ Hydrocarbons in IPOD Leg 63 sediments from outer California and Baja California borderlands. In Yeats, R.S., Haq, B.U., et al., Init. Repts. DSDP, 63: Washington (U.S. Govt. Printing Office), 775-784.

\section{Ms IR151-112}

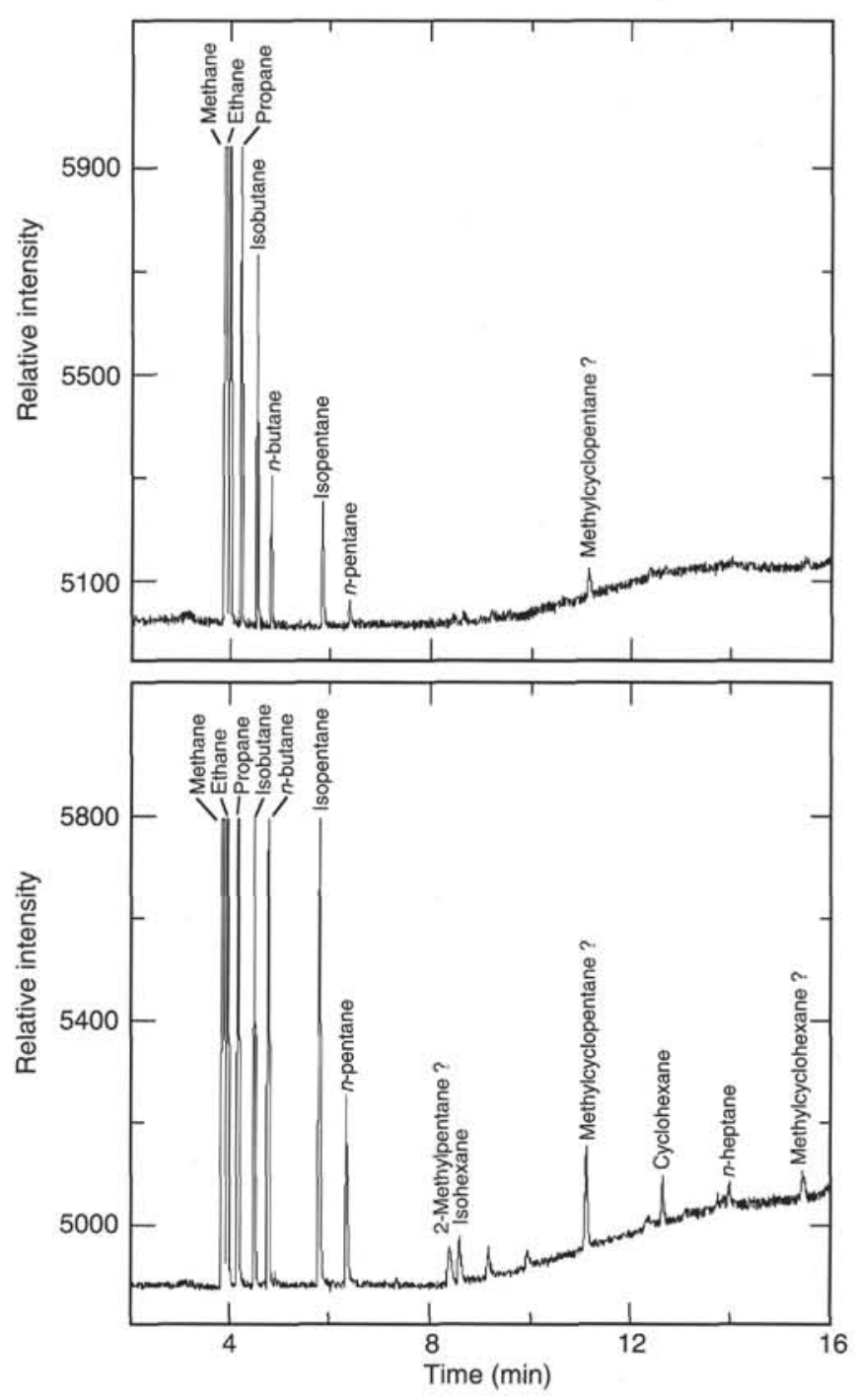

Figure 9. Two examples of natural gas analyzer gas chromatograms for Site 909 sediments. Core $151-909 \mathrm{C}-96 \mathrm{R}$ is from the interval above the sharp increase in gas concentrations; Core 151-909C-101R is from the lowermost interval characterized by distinctly increased concentrations of $\mathrm{C}_{3}-\mathrm{C}_{7}$ gases. 


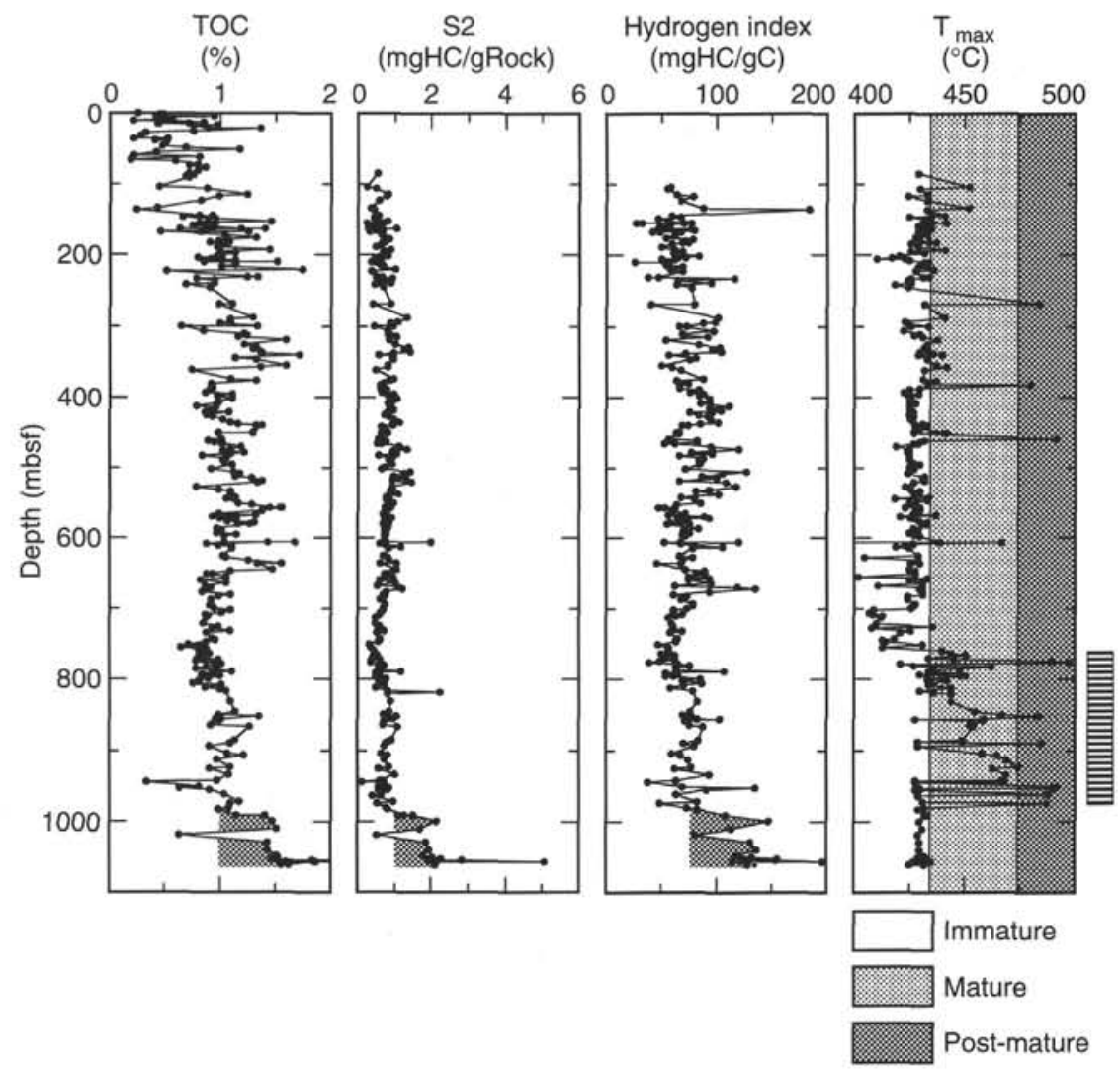

Figure 10. Total organic carbon content and Rock-Eval data ( $\mathrm{S} 2$ peak, hydrogen index, and $\mathrm{T}_{\max }$ values) for Site 909 sediments. The hatched vertical bar in the $T_{\max }$ plot indicates the presence of reworked, more mature organic matter.

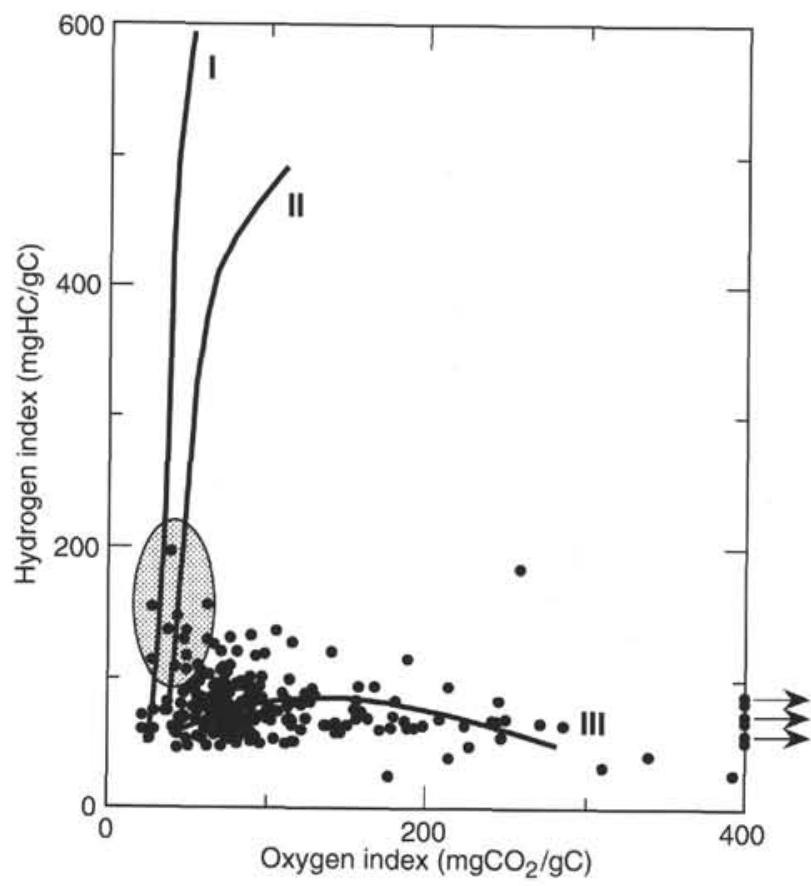

Figure 11. Hydrogen Index vs. Oxygen Index ("van Krevelen-type") diagram of sediments from Site 909. Circled field indicates samples from the lowermost part of the sedimentary sequence with immature organic material slightly enriched in hydrogen. Roman numerals indicate different types of organic matter: kerogen types I and II are mainly of marine origin, kerogen type III is terrigenous (cf. Éspitalié et al., 1977; Peters, 1986).

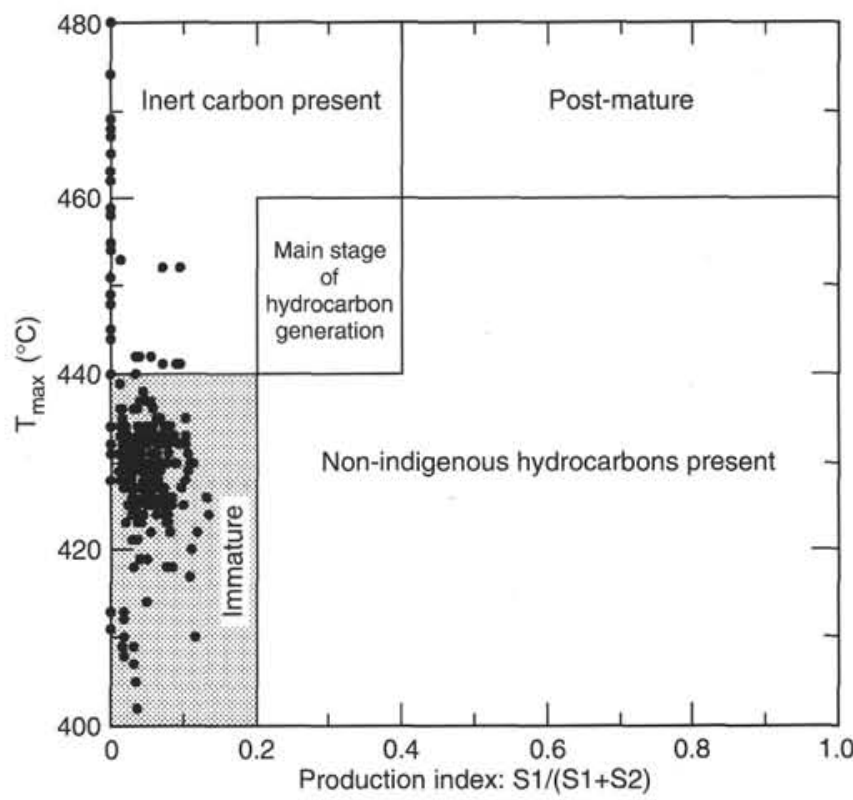

Figure 12. $\mathrm{T}_{\max }$ vs. production index diagram of sediments from Site 909, useful to identify stages of thermal maturity (after JOIDES PPSP, 1992). 
Table 1. Classification of source-rock potential, type of hydrocarbons generated, and level of thermal maturation (after Peters, 1986).

\begin{tabular}{|c|c|c|c|}
\hline \multicolumn{4}{|c|}{ Source rock potential } \\
\hline Quantity & $\begin{array}{l}\text { TOC } \\
\text { (wt\%) }\end{array}$ & $\underset{\text { (mgHC/gRock) }}{\mathrm{S} 1}$ & $\begin{array}{c}\mathrm{S} 2 \\
\text { (mgHC/gRock) }\end{array}$ \\
\hline $\begin{array}{l}\text { Poor } \\
\text { Fair } \\
\text { Good } \\
\text { Very good }\end{array}$ & $\begin{array}{c}0-0.5 \\
0.5-1.0 \\
1-2^{*} \\
>2^{*}\end{array}$ & $\begin{array}{c}0-0.5 \\
0.5-1^{*} \\
1-2 \\
>2\end{array}$ & $\begin{array}{c}0-2.5 \\
2.5-5^{*} \\
5-10^{*} \\
>10\end{array}$ \\
\hline \multicolumn{4}{|c|}{ Type of hydrocarbons generated } \\
\hline Type & $\begin{array}{l}\text { Hydrogen Index } \\
\text { (mgHC/gTOC) }\end{array}$ & $\mathrm{S} 2 / \mathrm{S} 3$ & \\
\hline $\begin{array}{l}\text { Gas } \\
\text { Gas and oil } \\
\text { Oil }\end{array}$ & $\begin{array}{c}0-150 \\
50-300^{*} \\
>300\end{array}$ & $\begin{array}{c}0-3^{*} \\
3-5^{*} \\
>5\end{array}$ & \\
\hline \multicolumn{4}{|c|}{ Level of thermal maturation } \\
\hline Maturation & $\begin{array}{c}\mathrm{PI} \\
(\mathrm{S} 1 /[\mathrm{S} 1+\mathrm{S} 2])\end{array}$ & $\begin{array}{l}\mathrm{T}_{\max } \\
\left({ }^{\circ} \mathrm{C}\right)\end{array}$ & $\begin{array}{l}\mathrm{R}_{\mathrm{o}} \\
(\%)\end{array}$ \\
\hline Immature & $<0.1^{*}$ & $<435^{*}$ & $<0.5$ \\
\hline Mature & $0.1-0.4$ & $435-470$ & $0.5-1.5$ \\
\hline Post-mature & $>0.4$ & $>475$ & $>1.5$ \\
\hline
\end{tabular}

Notes: $\mathrm{PI}=$ production index; $\mathrm{R}_{\mathrm{o}}=$ vitrinite reflectance. * = data from Site 909. 